\title{
Semiotics on Gotilon BATAK TOBa CEREMONy in Dolok Sanggul Humbang Hasundutan
}

\author{
Jerlin Hutasoit ${ }^{1}$, MORADA TETTY ${ }^{2}$, Sisila \\ FITRIANY DAMANIK ${ }^{3}$ \\ ${ }^{123}$ UNIVERSITAS NEGERI MEDAN
}

\begin{abstract}
The objectives of this study were to find out meanings, what, how, and why the meanings were realized in the Gotilon Batak Toba Ceremony in Dolok Sanggul Humbang Hasundutan. This study was conducted using an observation study. The data of this study were taken from Gotilon Ceremony. The sources of the data were the Gotilon Ceremony in Dolok Sanggul and the informants or Raja Parhata in Dolok Sanggul. The data were analyzed by using Roland's theory of semiotics object. The writer found the meanings on Gotilon Batak Toba Ceremony, namely: revise, support one, support two, support three, rid, speed, addition, exploitative two, exploitative three, survive, joyfulness, invitation, stay focus, keep fight, togetherness, convince, easier, kinship, honor, offering, and thanksgiving. From those materials were found that there were verbal utterances that consist of Atur biur, Angkat nomor sada, Angkat nomor dua, Angkat nomor tolu, Buang jauh-jauh, Eme, Rugi, Ponggol nomor dua, Ponggol nomor tolu, Naeng Sahat, Tambun Namboru, Hurre Alogo, Unang mekkel, Tahan nafas, Satukan, Beres. And there were symbols namely Luhutan, Marsirippa, Sipanganon, Mangamoti, and Pesta Gotilon. The signs used in Gotilon ceremony because they want to convey the meanings of the ceremony.
\end{abstract}

Keywords: Semiotics, Roland's theory, Gotilon, Toba ceremony 


\section{INTRODUCTION}

Semiotics is an academic field dedicated to the study of signs and symbols for what they communicate spoken and unspoken things that all have the meanings for every single sign or symbol. Semiotics cannot separated from human life, in daily activities so many signs can found and it can recognized by many forms such as forms of texts, images, performances, multimedia productions, traffic signals, fashion, action or objects, aromas (Chandler 2007). Semiotics is the study of signs, and how these signs stand-in for anything else.

Signs found in Batak Toba ceremonies. Which is happened in Gotilon ceremony. Gotilon is an activity done by humans to take the results of the rice plant when it has turned yellow. In the Gotilon Batak Toba ceremony, people have a habits hold their tradition by doing the Gotilon ceremony once a year. In Batak Toba, the function of rice is not just a staple food but more than. Rice has important symbolic function in Batak Toba culture. For example, Boras si Pir ni Tondi means "soul-strengthening rice". Symbolically, "strengthens the soul or spirit". Itak Gurgur means "rice flour" which is flaring up because of heat" (Gurgur). It is made the Gotilon is unique harvest than others. That is the meaning of symbolism to raise a weak spirit (soul) so that it gets exciting again. Indahan na Las "Warm Rice" is a symbol of warmth and joy. So from the statement-making, it is clear that the rice harvesting (Gotilon) is a special or different from any other harvest.

In the Gotilon Batak Toba ceremony in Dolok Sanggul Humbang Hasundutan There are several signs and symbols found it looks from the types of their words or utterances and several symbols. From the several signs, Batak Toba people need to understand the meaning of each sign on the Gotilon. Nowadays, no more people know the meanings of the signs and symbols on Gotilon, that is why the purpose of this study is to bridge the target in conveying deep meanings in the Gotilon Batak Toba ceremony. This study also to convey the denotative, connotative, and myth meaning as the realizations of the signs, and to describe the reasons for the sign realized.

\section{REVIEW OF LITERATURE}

\section{Semiotic theories}

Ferdinand De Saussure (1957) defined a sign as being composed of a 'signifier' (significant) and a 'signified' (signifié). Signifier and signified into two elements that make a sign. The signified and Signifier have a relationship that occurs in the realization. Where the Signifier is realized by Signified or Signified to realize the Signifier. This signified our conceptual component is not just a material object, it can be the thought or the idea of an object. The association between the signified and the signifier is arbitrary; it is mostly influenced by culture or context of use. In the case of media studies, a signifier is any image that is conveyed to the audience. Though signifiers and signified can be separated by semiologists; they form a unit called a "sign". 'Signifier' 
is interpreted as the material or physical thing of the sign that can seen, heard, touched, smelled, or tasted like a sound pattern. 'Signified' is known as the concept that refers to the object. In other words, Signifier refers to the physical aspects of a symbol, such as speech, image, and painting. While signified refers to the mental aspect of the symbol. The relationship between the physical existence of signs and mental concept means signification (Chandler, 2002). So, signification is an attempt to give meaning to the world.

Roland Barthes (1915-1980) develops semiotics into two levels of signification, namely the level of denotation and connotation. Denotation is a level of signification that explains the relationship of signifiers and signified to reality, producing explicit, direct, and certain meanings. The connotation is the level of signification that explains the relationship between the sign and the sign-in which the meaning of the operation is not explicit, indirect, and uncertain. The first order of signification is denotation. In this level, of sign that consisting of signifier and signified. The connotation is the second order of signification which uses the denotative sign (signifier and signified) as its signifier and attaches to it an additional signified. The connotation is a sign which derives from the signifier of a denotative sign. A signified on one level can become a signifier on another level. This is the mechanism by which signs may seem to signify one thing but loaded with multiple meanings (Chandler, 2002).

In the framework of Barthesian cultural studies, myth, like connotation, can be seen as a higher order of signification. Barthes stated that a myth is a culture's way of thinking about something, a way of conceptualizing or understanding it. Barthes thinks of a myth as a change of related concept. A myth is a story by which a culture explains or understands some aspect of reality or nature.

\section{Culture}

Culture is the form of traditional behaviors that is built by the members of society to show their identity or characteristic, includes belief, knowledge, law, morals, and etcetera. Culture word comes from Sanskrit, namely budddhayah, which is a plural form of buddha (mind or reason) interpreted as matters relating to the human mind and reason. Traditions are the community's traditionally cultural activities inherited orally from one generation to the other generation, the tradition is verbal or non-verbal (Sibarani, 2012).

Batak culture can interpreted as an area commonly called the Batak land. Batak Land is a local around Lake Toba, Batak people place, settled in North Sumatra. According to A.Sibeth, the Batak ethnic group is the largest ethnic group of Indonesians after Javanese, Sundanese, ChineseIndonesian, Madurese, and Malay. The Batak tribe consists of six sub-tribes, namely Angkola and Mandailing in the south, Toba in the center, Dairi and Pakpak in the west, Karo in the north, and Simalungun northeast.

\section{Gotilon}

Rice (Orizae Sativa L) is a plant that requires sufficient water in his life. This plant is classified as semi-aquatic which is suitable to be planted in flood location. Usually, rice is plant in 
rice fields that provide necessities enough water for growth. Even so, rice can also cultivated in dryland or fields, the term rice field. Harvest is the time when grain, fruit, or vegetable already to cut or pick.

Gotilon is the best opportunity for every people for the blessing received from God. In the Batak tradition, The Gotilon is the feast of the Great Harvest to express gratitude, joy, and awareness of the good variety of the perfect gift, blessing, fortune, maintenance, and protection of God in every step of our lives. This Gotilon party is already a momentous year for Batak people, that every year is always celebrate.

To supported this research, there are some relevant studies to this research that have been made by other researchers. These relevant studies also will be used as references and guidance to help the researcher have a deep understanding of signs so that the author can conduct her study in a good way.

The first previous study conducted by Sari (2016) analyzed Handbody lotion in television advertising, the research was the meanings and myths used to create beliefs regarding the advertising messages to the society. The purpose of this study was to determine the denotative meaning, connotative meaning, and myths contained in Citra Hand and body Lotion television commercials. This study is qualitative using the semiotic analysis of Roland Barthes.

The second previous study conducted by Azin (2015) analyzed woman's image in Iranian used Barthes's theory, This study is qualitative using to find out the meaning in denotation and connotation of Women's Image in Iranian TV Commercials Based on Barthes Visual Semiotics

The third previous study conducted by Kusuma (2017) analyzed ritual Otonan Bali, this research was found the signs on the ritual in Bali culture and found the meaning of denotation, connotation, and myth. The research paradigm was the research perspective used by researchers about how researchers see reality, how to study phenomena, ways used in research, and used to interpret findings. The constructivist paradigm sees a reality formed by a variety of backgrounds as a form of reality construction. This research analyzed from objective of the color, kind of their clothes, and utterances in their prayers. The constructivist paradigm aims to understand what constitutes reality's construction. Therefore researchers must be able to know what factors drive a reality can occur and can explain how these factors reconstruct the reality.

From those previous studies, it can shown that the study of signs on Gotilon Batak Toba ceremony is still rare. The writer also used Roland Barthes' theory which is proper with this research object. The research is related to culture and history. Therefore, this research used the same theory as previous studies.

\section{RESEARCH METHODOLOGY}

This study conducted by using an observation study by Creswell, J. W. (2014). It was observation in which the writer is interested in the meaning, and understanding gained through verbal utterances or symbols. The writer focused on analyzing semiotics on Gotilon Batak Toba ceremony in Dolok Sanggul 
to find the meanings of the signs and describe the meaning of the signs.

The data were symbols and verbal utterances in the Gotilon Batak Toba ceremony. The source of the data was the Gotilon Batak Toba ceremony and also interview three informants ( raja Parhata) who knew well about Gotilon in Dolok Sanggul at Sitio II- Hutasoit village.

To collected the data, the writer observing during the Gotilon ceremony, the next was documentation by relating to the object of research. In this study, the document is in the form of pictures, videos, and audio record, and then the writer also interviewing to find data stored in documents.

To analyzed the data, they were through the following steps, first was organizing all the signs containing symbols and verbal utterances on Gotilon Batak Toba ceremony. The second was reading and understanding the data obtaining a general sense of the information and reflecting on it is overall meaning. The third was describing the meaning and the realizations of all the signs using Roland's theory of sign: denotation, connotation, and myth. The last was elaborating on the meaning of the Gotilon ceremony in Dolok Sanggul.

\section{FINDINGS and DISCUSSIONS}

The writer found twenty-one signs, including verbal utterances ans symbols on Gotilon ceremony. There were 16 verbal utterances that consist of Atur biur, Angkat nomor sada, Angkat nomor dua, Angkat nomor tolu, Buang jauh-jauh, Eme, Rugi, Ponggol nomor dua, Ponggol nomor tolu, Naeng sahat /naeng tambun, Tambun namboru, Hurre alogo, Unang mekkel, Tahan nafas, Satukan, Beres. There were 5 symbols that consist of Luhutan, Marsirippa, Sipanganon, Mangamoti, and Pesta Gotilon.

Table I.

The meanings semiotically coded on Gotilon Batak Toba

\begin{tabular}{|c|c|c|c|c|}
\hline \multirow[t]{2}{*}{ No } & \multirow[t]{2}{*}{ Semiotic } & \multirow[t]{2}{*}{ SemioticMeaning } & \multicolumn{2}{|c|}{ Sign Types } \\
\hline & & & $\begin{array}{c}\text { Verbal } \\
\text { Utterances }\end{array}$ & Symbols \\
\hline 1 & $\begin{array}{l}\text { Atur Biur } \\
\text { ( rice rule ) }\end{array}$ & Revise & $\sqrt{ }$ & - \\
\hline 2 & $\begin{array}{l}\text { Angkat nomor Sada } \\
\text { ( Raise number one ) }\end{array}$ & Support one & $\sqrt{ }$ & - \\
\hline 3 & $\begin{array}{l}\text { Angkat nomor Dua } \\
\text { ( Raise number three ) }\end{array}$ & Support two & $\sqrt{ }$ & - \\
\hline 4 & $\begin{array}{l}\text { Angkat nomor Tolu } \\
\text { ( Raise number three) }\end{array}$ & Support three & $\sqrt{ }$ & - \\
\hline 5 & Buang Jauh-jauh & Rid & $\sqrt{ }$ & - \\
\hline
\end{tabular}




\begin{tabular}{|c|c|c|c|c|}
\hline & ( Throw far away) & Speed & $\sqrt{ }$ & - \\
\hline 6 & $\begin{array}{l}\text { Eme } \\
\text { ( Rice ) }\end{array}$ & Addition & $\sqrt{ }$ & - \\
\hline 7 & $\begin{array}{l}\text { Rugi } \\
\text { ( Less fortune) }\end{array}$ & Exploitative two & $\sqrt{ }$ & - \\
\hline 8 & $\begin{array}{l}\text { Ponggol nomor Dua } \\
\text { ( Cut for number two ) }\end{array}$ & Exploitative three & $\sqrt{ }$ & - \\
\hline 9 & $\begin{array}{l}\text { Ponggol nomor Tolu } \\
\text { ( Cut for number three) }\end{array}$ & Survive & $\sqrt{ }$ & - \\
\hline 10 & $\begin{array}{l}\text { Naeng Sahat / Tambun } \\
\text { ( Almost arrived) }\end{array}$ & Joyfulness & $\sqrt{ }$ & - \\
\hline 11 & $\begin{array}{l}\text { Tambun Namboru } \\
\text { ( Finished ) }\end{array}$ & Invitation & $\sqrt{ }$ & - \\
\hline 12 & $\begin{array}{l}\text { Hurre Alogo } \\
\text { ( Come on wind) }\end{array}$ & Stay focus & $\sqrt{ }$ & - \\
\hline 13 & $\begin{array}{l}\text { Unang mekkel } \\
\text { ( No laughing) }\end{array}$ & Keep fight & $\sqrt{ }$ & - \\
\hline 14 & $\begin{array}{l}\text { Tahan nafas } \\
\text { ( Hold breath ) }\end{array}$ & Togetherness & $\sqrt{ }$ & - \\
\hline 15 & $\begin{array}{l}\text { Satukan } \\
\text { ( Unite ) }\end{array}$ & Convince & $\sqrt{ }$ & - \\
\hline 16 & $\begin{array}{l}\text { Beres } \\
\text { ( Right ) }\end{array}$ & Easier & - & $\sqrt{ }$ \\
\hline 17 & $\begin{array}{l}\text { Luhutan } \\
\text { ( Circle of the rice) }\end{array}$ & Kinship & - & $\sqrt{ }$ \\
\hline 18 & $\begin{array}{l}\text { Marsirippa } \\
\text { ( Cooperate ) }\end{array}$ & Honor & - & $\sqrt{ }$ \\
\hline 19 & $\begin{array}{l}\text { Sipanganon } \\
\text { ( Foods ) }\end{array}$ & Offering & - & $\sqrt{ }$ \\
\hline 20 & $\begin{array}{l}\text { Pesta Gotilon } \\
\text { ( Gotilon party ) }\end{array}$ & Thanksgiving & - & $\sqrt{ }$ \\
\hline 21 & $\begin{array}{l}\text { Mangamoti } \\
\text { ( Taste ) }\end{array}$ & & & \\
\hline
\end{tabular}

\section{Atur biur}

Denotation : Doer number one shout Biur to Pambiur or the rice divider with a loud voice, it found there was a mess of rice stalks in his hand so it cannot grasped properly. 
Connotation : An utterance as a warning to Pambiur. Because Pambiur is unable to carry out consistency from beginning to end, there were obstacles that make Pambiur nervous about his work so that the rice that distributed is less organized than it should be

Myth : "Sala mandasor sega luhutan" when the work in the beginning is wrong, it will end wrong as well

\section{Angkat nomor sada}

Denotation : Doer number two and three shouts Angkat nomor sada alternately loudly, there is still a lot rice that lives on the rice stalk that held

Connotation : Utterance warning that must be said to doer number one because it does not work consistent when hitting the rice stalk from beginning to end. Doer number one is to focus as a prisoner in the hitting. In front as an example.

Myth : The results will not be maximal if number one is not able to be the strongest

\section{Angkat nomor dua}

Denotation : Doers number one and three shouts Angkat nomor dua alternately loudly, there is still a lot rice that lives on the rice stalk that held

Connotation : Utterance warning that must be said to doer number two because it does not perform consistent when hitting the rice stalk from beginning to end and on the way of hitting was unfocus

Myth $\quad:$ Spirit of number two affect the spirit of the first and third players

\section{Angkat nomor tolu}

Denotation : The doers of number two and Pambuang shout Angkat nomor tolu alternately loudly, the third doer hit slowly

Connotation : Utterance warning that must be said to doer number three because it does not perform consistently when hitting the rice stalk from beginning to end and on the way of hitting was slowly

Myth :Spirit of number three affect the spirit of the second players

\section{Buang jauh-jauh}

Denotation :The doer ofnumber three shout buang jauh-jauh to Panippal (thrower), panippal throws his rice stalks near and it even covers the mat area

Connotation :This utterance reminds us that clean rice stalks must be removed and separated from rice grains so is not to confuse or increase work to collecting rice.

Myth :Garbage will only disrupt the activity can also hurt

6. Eme

Denotation $\quad$ :Biur shout eme to Parohon because the rice to be distributed by the biur already looks a little

Connotation : Utterance to Parohon due to delays in lifting rice from the Luhutan to the mat area so that this can take more rest time than harvesting 
Myth :One's backwardness in cooperation affects all members

7. Rugi

Denotation :The doer number one, two and three shout loss to Biur because the rice distributed is not following the doer's handgrip or too little rice

Connotation :Warning utterance to Pambiur because he was unable to carry out consistency from the beginning to the end in distributing rice stalks because it would be detrimental to doer number one, two, and three. Many pieces of rice distributed affected the sound of beatings and the seriousness of the doer in the harvest

Myth :Big is better than small, even when the harvest is finished all doers shouted Tambun which means added even though the yield at that time decreased from the usual

\section{Ponggol nomor dua}

Denotation : Shout ponggol nomor dua because the rice stalks that discarded are less clean, the rice seeds are still sticky in the stems that thrown away

Connotation : Utterance so that Doer number two not only focuses on hitting hard and strongest but must also look at how to hit it so that the rice stalk is clean from the stem to the top

Myth :The proverbial gradually becomes a hill, no matter how small the results should not discarded

\section{Ponggol nomor tolu}

Denotation : Shout ponggol nomor tolu because the rice stalks that discarded are less clean, the rice seeds are still sticky in the stems that thrown away

Connotation :Utterance so that doer number three not only focuses on hitting hard and strong but must also look at how to hit it so that the rice stalk is clean from the stem to the top

Myth :The proverbial gradually becomes a hill, no matter how small the results should not discarded

\section{Naeng sahat / Tambun}

Denotation : Parohon shout an utterance naeng sahat with a happy face, all the doers look tougher in hitting rice and their enthusiasm in doing their part

Connotation : Utterance joy to each doer to know the extent of their harvest journey, utterance as a signal to keep the spirit and survive in cohesiveness

Myth :Enthusiasm will increase when knowing the destination will arrive soon

\section{Tambun namboru}

Denotation : The rice harvest is over, all the doers shout alternately Tambun namboru with a face of relief and joy and all the doers take time to rest for a while

Connotation :The utterance was happy and grateful because they had succeeded in reaping the rice they had sown for more than 6 months

Myth : Be grateful when reap the results of plant

\section{Hurre alogo}

Denotation : Pamurpur shout hurre alogo when the wind feels slow because the slow wind 
cannot set aside the rice that contains and which does not contain the one being hand carry

Connotation :Utterance to call agin so that the wind comes louder and the work of removing rice that is filled and not filled is finish quickly

Myth :When someone call the name of something, it comes immediately

\section{Unang mekkel}

Denotation : Parents advise and scold children who are laughing at harvest time, after being advised they do not laugh anymore

Connotation : Utterance advised that in a harvest do not be arrogant or feel spree but should be more bent down as well as rice which is more filled then he will increasingly bow

Myth : The devil will be slapp someone mouth who laugh while working in the Fields

\section{Tahan nafas}

Denotation :Parohon shout tahan nafas to all members of the doer because they are looking monotonous, weak, and no longer excited, especially for number one, two, and three

Connotation : Utterance warns all doers to always work with enthusiasm, because soon it will be resting or the harvest will soon be over

Myth : End the work until it's finished so that there are no distractions while sleeping

\section{Satukan}

Denotation :Panippal shout satukan for the doer's number one, two and three ws are not simultaneous and not too loud

Connotation : Utterance warning to doers number one, two, and three so that they are not careless in hitting the rice and so that the spirit and strength remain the same from the beginning to the end of the harvest

Myth : Excitement will flow when others are excited and enthusiastic

16. Beres

Denotation : The shout of doers goes out loud and loud to respond to the shout before

Connotation : Utterance to emphasize that the doer is fine and will do the same job as his energy and enthusiasm in the beginning as well as a sign that he is still playing and there are no signs of wanting to rest or replace the position

Myth : Do not ignore

From the result above, it can concluded that verbal utterances on Gotilon Batak Toba ceremony because verbal utterances on Gotilon were an advised or rebuke for the workers with the aim to create a good utterance, not to hurt somebody when they have to be advised or rebuke in doing the work. The intonation of the utterances are not coarseness but to encourage the workers.

\section{Luhutan}

Denotation : Luhutan is the circle of rice that already yellowed color, pinched, and made in a circle without using pouring

Connotation : Seen a picture of rice in the form of a circle in which is lower and has a wall so that it can used to put the harvesting tools, and so that it can carry out harvesting activities in the 
circle area

Myth : Luhutan simplifies the harvest process

\section{Marsirippa}

Denotation

: Picture marsirippa or cooperation, take and play each other's work which is a matter that is interrelated with one another. someone was lifting rice, handing out, hitting, cleaning, inside the harvest area

Connotation : Every body doing their part without anyone regulating or ordering because they do their duties according to their strengther

Myth : Handle each other's self and respect each other

\section{Sipanganon}

Denotation : In the picture, you can see sipanganon or foods includ meat, noodles, rice, fish, and tea. The picture shows that during harvest time the food must be better than usual and more servings

Connotation : That when we are with other people and have heavy work, it is proper to have to eat good and lots of food so that the energy to continue working will well soon

Myth : Health is more important than anything

\section{Mangamoti}

Denotation : A woman hold Andalu, both with her hands to pound rice that has inserted into a mortar, there is rest beside her which is to pounding the rice

Connotation : The process of processing rice into rice in the traditional way, pounding it with a hand in a mortar, and cleaning it with the tray

Myth : Taste the crops before anyone else

\section{Pesta Gotilon}

Denotation : Mothers who sit on chairs and put a tandok beside each other while taking turns to bring the tandok (rice harvest) to the church as an offering to God called the party Gotilon or bring the rice harvest guided by a priest

Connotation : In the culture and customs of the Toba Batak to bring rice must use Tandok and what is brought in by the mothers and the results of the completed rice harvest will be offered to God as a sign of gratitude

Myth : All the results obtained are God's blessings

From the result above, it can concluded that symbols on Gotilon Batak Toba ceremony used because symbols In tradition ceremonies for Batak people, there are a lot of meaning of signs used in Gotilon ceremonies. During the Gotilon ceremony, people used symbols that to convey the message of the teaching of the Gotilon Batak Toba ceremony to function and art of communicating in all aspects of life.

\section{CONCLUSIONS AND SUGGESTIONS}




\section{Conclusions}

All the signs that used in Gotilon ceremony have different reasons for the realization. In this research, the writer divided the sign classification. There were 21 meanings found in the Gotilon ceremony and 21 objects of sign that consist of 16 verbal utterances and 5 symbols, It showed how semiotics realized in the ceremony. The reason for the meanings realized in the Gotilon Batak Toba ceremony in Dolok Sanggul is from some certain situations. Certain situations are accompanied by utterances as expressions shout of someone for the woker to advise or rebuke. This ceremony also is known by some people as habits. Traditional habits that have been maintained for a long time will increasingly develop and it is the traditional habit that needs to be preserved.

\section{Suggestion}

The writer suggests that by understanding the theory, it is essential to the students, readers should learn more about semiotics in culture. Moreover for Batak Toba people, especially younger generations are expected to understand the reason for the realization of symbols in Gotilon ceremony as their culture and tradition and for another researcher, this study can used as a reference analysis for another ceremony

\section{REFERENCES}

Adebola, Abosede, Otemuyiwa. (2017). Semiotics in the Whatsapp Conversations of Undergraduate Students of Obafemi Awolo University, Ile Ife, Osun State, Nigeria.Creative Commons Attribution License 4.0. 8(5). 43-62

Azin, Nooshin, Hossein. (2015). Analysis of Women's Image in Iranian TV Commercials Based on Barthes Visual Semiotics. Social Sciences. 6 (6). 414-422

Barthes, Roland. (1972). Mythologies. Annette Lavers. New York: Hill and Wang

Chandler, Daniel. (2002). Semiotics the Basics. USA dan Kanada: Routledge

Chandler, Daniel. (2007). Semiotics The Basics (Second Edition). New York: Routledge.

Creswell, j. W. (2014). Research Design Quality, Quantitative and MixedMethods Approaches. Los Angelos: SAGE Publication, Inc.

Eco, Umberto. (2009). Teori Semiotika, Bantul: Kreasi Wacana. 
Izzarine Nurdiaz Pramudita, Muhammad Edy Susilo, Christina Rochayanti. (2017). Analysis Of Signs And Meanings In Sariayu Hijab Haircare Advertisements (Semiotic Analysis of Instagram Account. The Indonesian Journal of Communication Studies, 10(2), 94-107.

Kusuma, Putu, Iis Kurnia Nurhayati. (2017). Analisis Semiotika Roland Barthes Pada Ritual Otonan Di Bali. Manajemen Komunikasi. 1(2). 195-217

Rossolatos, George. (2017). The semiotics of monitory language Branding: A Study of the Celtic Languages. Universitat Kassel. 5. 1-33

Sari, Febri, Ratih, Itca. (2016). Representation Of Indonesian Women's Beauty In The Television Advertising Of Citra Handbody Lotion “Dari Citra Untuk Indonesia”. Sosioteknologi. 15 (1). 86-95.

Sianipar. (2012). Nilai Budaya Batak Toba. Jakarta: Sanggar William Iskandar.

Sibarani. (2014). Kearifan Lokal: Hakikat, Peran dan Metode Tradisi Lisan. Jakatra: Sanggar William Iskandar. 